\title{
Inhibition by Lithium of Cyclic GMP Formation without Inhibition of Nitric Oxide Generation in the Mouse Neuroblastoma Cell (N1E-115)
}

Futoshi Shintani, M.D., Shigenobu Kanba, M.D., D.M.S., Toshio Nakaki, M.D., D.M.S., Ryoko Nakamura, Koichi Sato, M.D., Gohei Yagi, M.D., D.M.S., Elliott Richelson, M.D., Ph.D., Ryuichi Kato, M.D., D.M.S., and Masahiro Asai, M.D., D.M.S.

We investigated the effects of lithium ion $\left(\mathrm{Li}^{+}\right)$on muscarinic receptor-mediated nitric oxide (NO) generation, and guanylate cyclase (GCase) activation using the mouse neuroblastoma clone, N1E-115. The levels of released NO were determined by measuring the levels of nitrite/nitrate in the incubation medium, and the activity of GCase was measured with an assay for cellular cyclic $\left[{ }^{3} \mathrm{H}\right] \mathrm{GMP}$ levels. We determined that $\mathrm{Li}^{+}$had no effects on muscarinic receptor-activated elevation of nitrite/nitrate levels, which were significantly inhibited by $100 \mu \mathrm{M} \mathrm{L-N} \mathrm{N}^{\mathrm{G}}$-monomethylarginine, although it has been reported that $\mathrm{Li}^{+}$inhibits muscarinic receptoractivated cyclic GMP formation in the cells. In addition, $\mathrm{Li}^{+}$inhibited the cyclic GMP formation induced by an NO donor, sodium nitroprusside (SNP), in both intact cells and a crude cellular homogenate; thus, the inhibition by $\mathrm{Li}^{+}$of muscarinic receptor-mediated cyclic GMP synthesis appeared to be at the level of GCase, but not NO synthase. INeuropsychopharmacology

11:119-124, 1994]
KEY WORDS: Lithium chloride; Nitric oxide; Cyclic GMP; N1E-115 cells; Muscarinic receptor; Sodium nitroprusside

Lithium $\left(\mathrm{Li}^{+}\right)$is often prescribed for patients with manic depressive illness (MDI), and has a preventive effect for recurrence of MDI (Cade 1949; Schou 1968). The precise mechanisms underlying the effects of $\mathrm{Li}^{+}$ in such psychiatric illnesses as MDI remain unknown. Hokin and Hokin (1953) reported that activation of muscarinic receptors stimulated the breakdown of phospha-

From the Departments of Neuro-psychiatry (FS, SK, RN, KS, GY, MA) and Pharmacology (TN, RK), Keio University School of Medicine, Tokyo 160, Japan; and Departments of Psychiatry and Pharmacology (ER), Mayo Clinic Jacksonville, FL.

Address correspondence to Shigenobu Kanba, M.D., Department of Neuro-psychiatry, Keio University School of Medicine, Shinanomachi 35, Shinjuku-ku, Tokyo 160, Japan.

Received October 19, 1993; revised March 24, 1994; accepted March 31, 1994. tidylinositol (PI), and it has been shown that $\mathrm{Li}^{+}$ caused the accumulation of the product of this breakdown, myo-inositol-1-phosphate, in the brain through inhibition of myo-inositol-1-phosphatase (Hallcher and Sherman 1980; Berridge 1984). Although many investigations have focused on the PI cycle as the site of therapeutic action of this ion, no consensus as to the basic mechanism of $\mathrm{Li}^{+}$actions has yet been established.

We have already reported that $\mathrm{Li}^{+}$significantly inhibited cyclic GMP formation induced by stimulation with carbamylcholine, a muscarinic receptor agonist, by using a mouse neuroblastoma clone: N1E-115 cells (Kanba and Richelson 1984; Kanba et al. 1986). In addition, when sodium channel was activated, $\mathrm{Li}^{+}$had an increased potent intracellular effect (Kanba et al. 1991). We hypothesized that the inhibitory action of $\mathrm{Li}^{+}$on cyclic GMP formation may be associated with its clinical efficacy and toxicity, and that the action may become 
increasingly potent in pathologically-active neurons underlying manic-depressive disorder.

Conversely, in many types of cells, guanylate cyclase (GCase) is activated by nitric oxide (NO), which is produced by nitric oxide synthases (NOS) from L-arginine (Knowles et al. 1989; Garthwaite 1991). Activation of the muscarinic receptors on N1E-115 cells can also induce production and release of $\mathrm{NO}$ by mediating the activation of NOS (Arroyo and Forray 1991). Despite our results and those of others, we hypothesized that the inhibitory effects of $\mathrm{Li}^{+}$on cyclic GMP formation are due to inhibition of NO synthesis, or GCase activation. The present studies were designed to investigate the mechanism by which $\mathrm{Li}^{+}$inhibits the muscarinic receptor-mediated cyclic GMP formation. First, to assess the possibility that $\mathrm{Li}^{+}$inhibits receptormediated $\mathrm{NO}$ synthesis, we examined if $\mathrm{Li}^{+}$inhibits muscarinic receptor-mediated NO generation in N1E115 cells by measuring the nitrite/nitrate levels in the incubation medium. Second, in order to determine if $\mathrm{Li}^{+}$directly inhibits activation of guanylate cyclase, we determined the guanylate cyclase activity in both intact cells and a crude homogenate of N1E- 115 cells containing several concentrations of $\mathrm{Li}^{+}$by measuring the levels of cyclic GMP elicited by SNP.

\section{METHODS}

\section{Cell Culture}

N1E-115 cells (passages 12-14) were cultured in Dulbecco's MEM as described previously (Kanba and Richelson 1984). The cells were used for the experiment when they had reached a state of confluence in $25 \mathrm{~cm}^{2}$ culture flasks (Corning).

\section{Assay of Nitrite/Nitrate Levels in the Incubation Medium of N1E-115 Cells}

After the cells had been washed three times with $3 \mathrm{ml}$ of Hanks' solution $(137 \mathrm{mM} \mathrm{NaCl}, 5.4 \mathrm{mM} \mathrm{KCl}, 1.3 \mathrm{mM}$ $\mathrm{CaCl}_{2}, 0.8 \mathrm{mM} \mathrm{MgSO}_{4}, 0.338 \mathrm{mM} \mathrm{Na} \mathrm{HPO}_{4}, 0.4 \mathrm{mM}$ $\mathrm{KH}_{2} \mathrm{PO}_{4}, 5.6 \mathrm{mM}$ glucose, $4.2 \mathrm{mM} \mathrm{NaHCO}, \mathrm{pH} 7.4$ ), they were preincubated at $37^{\circ} \mathrm{C}$ for $30 \mathrm{~min}$ in $3 \mathrm{ml}$ of Hanks' solution. Five-hundred microliters of the incubation medium were collected, and $2.5 \mu \mathrm{l}$ of $100 \mathrm{mM}$ L-N $\mathrm{N}^{\mathrm{G}}$-monomethylarginine (L-NMMA), for inhibition of NOS, or vehicle was added. The cells were then stimulated with carbamylcholine to achieve $0.01,0.03$, $0.1,0.3,1$, or $3 \mathrm{mM}$ as a final concentration. Five-hundred microliters of the incubation medium were collected again at 30 seconds after stimulation.

In another series of experiments, after the cells had been washed three times as described previously, they were preincubated at $37^{\circ} \mathrm{C}$ for 30 minutes in $3 \mathrm{ml}$ of Hanks' solution containing various concentrations of lithium chloride $(\mathrm{LiCl})$, sodium chloride $(\mathrm{NaCl})$, or ammonium chloride $\left(\mathrm{NH}_{4} \mathrm{Cl}\right)$. Five-hundred microliters of the incubation medium were collected immediately before and 30 seconds after stimulation with $1 \mathrm{mM}$ carbamylcholine. Two and one half microliters of $100 \mathrm{mM}$ L-NMMA, or vehicle were added immediately before stimulation.

When the series of experiments had been completed, the numbers of cells were counted after scraping. Nitrite/nitrate concentrations in the incubation medium were quantitated with an automated system based on the Griess reaction (Hishikawa et al. 1992). The values obtained by subtracting nitrite/nitrate levels before stimulation from those obtained after stimulation were regarded as nitrite/nitrate derived from the cells.

\section{Assay of Cyclic GMP Levels in Intact N1E-115 Cells}

N1E-115 cells were cultured as described previously. Detached and washed N1E-115 cells were suspended in $3 \mathrm{ml}$ of physiological iso osmolar phosphate buffer containing saline with glucose and sucrose (PBS; 110 $\mathrm{mM} \mathrm{NaCl}, 5.3 \mathrm{mM} \mathrm{KCl}, 1.8 \mathrm{mM} \mathrm{CaCl}, 1 \mathrm{mM} \mathrm{MgCl}$, $25 \mathrm{mM}$ glucose, $2 \mathrm{mM} \mathrm{Na} \mathrm{HPO}_{4} ; \mathrm{pH}$ adjusted to 7.35; osmolarity adjusted to $335 \pm 5 \mathrm{mOsmol}$ with sucrose) at $37^{\circ} \mathrm{C}\left(3-5 \times 10^{6}\right.$ cells $\left./ \mathrm{ml}\right)$. The cells were transferred to a $25-\mathrm{ml}$ Erlenmeyer flask and $30 \mu \mathrm{Ci}$ of $\left[{ }^{3} \mathrm{H}\right]$ guanine was added. The cells were placed in a shaker bath at $37^{\circ} \mathrm{C}$ and incubated for $45 \mathrm{~min}$. After labeling with $\left[{ }^{3} \mathrm{H}\right]$ guanine, the cells were centrifuged gently, and the supernatant containing excess radioactivity was aspirated. The pelleted cells were then resuspended in PBS at $37^{\circ} \mathrm{C}$ to about 3 to $4 \times 10^{5}$ cells $/ \mathrm{ml}$, and were distributed into the wells of a multiwell plate in 320- $\mu$ laliquots. Several concentrations of $\mathrm{LiCl}, \mathrm{NaCl}$, and $\mathrm{NH}_{4} \mathrm{Cl}$ were then added in a $100-\mu \mathrm{l}$ aliquot, and the cells were further incubated at $37^{\circ} \mathrm{C}$ for 30 minutes. The cells were stimulated with sodium nitroprusside (SNP; an $80-\mu$ l aliquot), to achieve $10,25,50,100,200,300$, or $400 \mu \mathrm{M}$ as the final concentration, for 30 seconds. The assay was stopped with the addition of $50 \mu \mathrm{l}$ of $50 \%$ trichloroacetic acid. The levels of cyclic $\left[{ }^{3} \mathrm{H}\right] \mathrm{GMP}$ were then determined as described previously (Richelson et al. 1978).

\section{Assay of Guanylate Cyclase Activity in Homogenates of N1E-115 Cells}

Detached and washed cells were suspended in $50 \mathrm{mM}$ Tris- $\mathrm{HCl}$ buffer $\left(\mathrm{pH} 7.6\right.$ at $\left.37^{\circ} \mathrm{C}\right)$ to about 2 to $3 \times 10^{6}$ cells $/ \mathrm{ml}$. The cells were then sonicated for 30 seconds (setting no. 3, Ultrasonic Cell Disrupter, Kontes Glass Co., Vineland, NJ) on ice. The assay of GCase activity was begun with the addition of $50 \mu$ l of the cell homogenate to the reaction cocktail. The final volume of the 


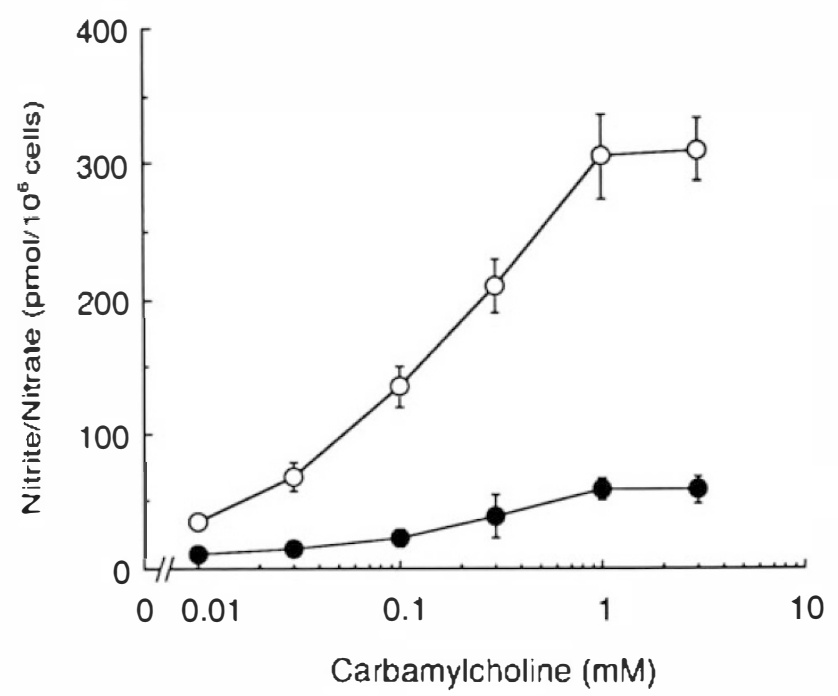

Figure 1. Nitrite/nitrate levels in the incubation medium of intact N1E-115 cells following 30 sec carbamylcholine stimulation (O). Carbamylcholine enhanced the levels of nitrite/ nitrate in a dose dependent manner, and the elevation of nitrite/nitrate levels was significantly inhibited by preincubation with $100 \mu \mathrm{M} \mathrm{L-NG}$-monomethylarginine ( $\mathbf{0})$. Circles and vertical bars represent means and SEM, respectively, of five independent experiments. Circles without bars indicate that the size of the circle is greater than the length of the bar.

assay was $150 \mu \mathrm{l}$ and consisted of the following: $50 \mathrm{mM}$ Tris- $\mathrm{HCl}$ (pH 7.6); $5 \mathrm{mM} \mathrm{MgCl}_{2} ; 0.5 \mathrm{mM}$ 3-isobutyl-1methylxanthine; $2.5 \mathrm{mM}$ cyclic GMP; $5 \mathrm{mM}$ creatine phosphate; $0.6 \mathrm{U}$ of creatine phosphokinase; $0.25 \mathrm{mM}$ GTP; 3 to $4 \times 10^{5} \mathrm{dpm}$ of [ $\left.{ }^{3} \mathrm{H}\right] \mathrm{GTP}$; several concentrations of $\mathrm{LiCl}$ and SNP. Incubations were carried out at $37^{\circ} \mathrm{C}$ for 5 minutes and reactions were stopped by the addition of $30 \mu \mathrm{l}$ of $50 \%$ trichloroacetic acid. The cyclic $\left[{ }^{3} \mathrm{H}\right] \mathrm{GMP}$ formed was determined as described previously (Richelson et al. 1978).

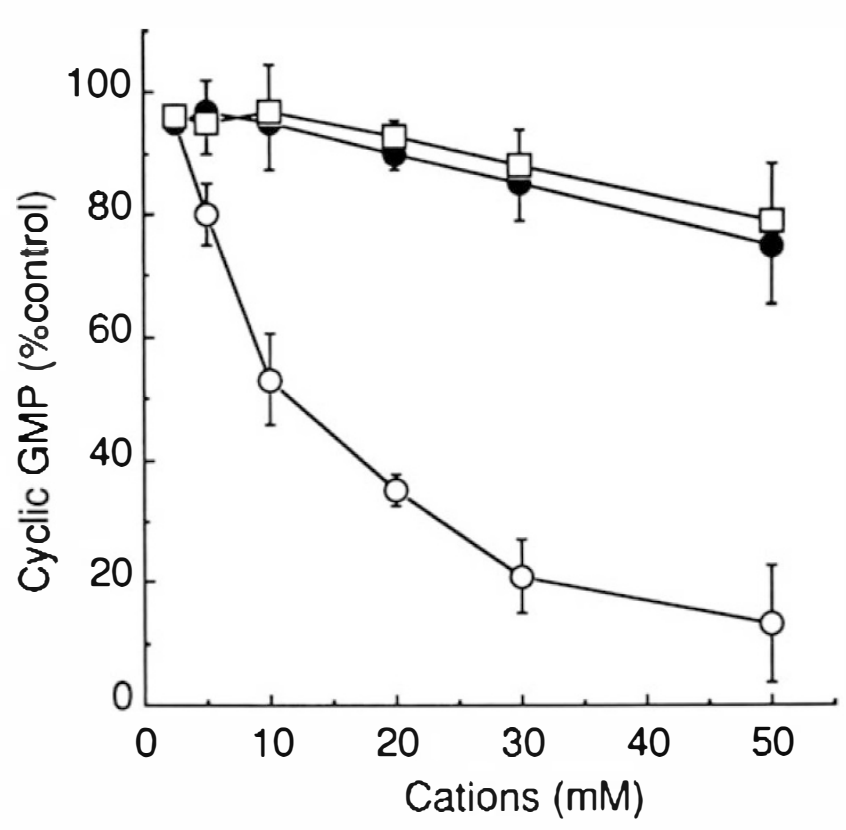

Figure 2. Effect of 30 min preincubation with $\mathrm{LiCl}, \mathrm{NaCl}$, or $\mathrm{NH}_{4} \mathrm{Cl}$ on $300 \mu \mathrm{M}$ SNP-activated cyclic GMP formation in intact N1E-115 cells. The ordinate represents the percentage for cyclic GMP levels elicited by $300 \mu \mathrm{M}$ SNP in the absence of cations. $\mathrm{LiCl}$ inhibited the elevated cyclic GMP formation in a dose-dependent manner $(\bigcirc) . \mathrm{NaCl}(\bigcirc)$ and $\mathrm{NH}_{4} \mathrm{Cl}(\square)$ showed no significant inhibitory effects. For circles and vertical bars, see legend in Figure 1.

\section{RESULTS}

\section{Effects of LiCl on Muscarinic Receptor-activated Nitrite/Nitrate Derived from N1E-115 Cells}

Carbamylcholine enhanced the levels of nitrite/nitrate in the incubation medium in a dose dependent manner, and the elevation of nitrite/nitrate levels was

Table 1. The Effects of $\mathrm{LiCl}, \mathrm{NaCl}$, and $\mathrm{NH}_{4} \mathrm{Cl}$ of Concentrations on Muscarinic Receptor-activated Nitrite/Nitrate Levels in the Medium

\begin{tabular}{|c|c|c|c|c|c|c|}
\hline \multirow{2}{*}{$\begin{array}{l}\text { Concentration } \\
(\mathrm{mM})\end{array}$} & \multicolumn{3}{|c|}{$\begin{array}{l}\text { Nitrite/Nitrate } \\
\text { (pmol } / 10^{6} \text { cells) }\end{array}$} & \multicolumn{3}{|c|}{$\begin{array}{l}100 \mu \mathrm{M} L-N^{G}- \\
\text { monomethyl- } \\
\text { arginine }\end{array}$} \\
\hline & $\mathrm{LiCl}$ & $\mathrm{NaCl}$ & $\mathrm{NH}_{4} \mathrm{Cl}$ & $\mathrm{LiCl}$ & $\mathrm{NaCl}$ & $\mathrm{NH}_{4} \mathrm{Cl}$ \\
\hline 2.5 & $303 \pm 25$ & $298 \pm 31$ & $289 \pm 37$ & $60 \pm 6$ & $59 \pm 9$ & $62 \pm 8$ \\
\hline 5 & $300 \pm 30$ & $301 \pm 25$ & $294 \pm 29$ & $57 \pm 9$ & $62 \pm 10$ & $50 \pm 15$ \\
\hline 10 & $290 \pm 38$ & $295 \pm 28$ & $305 \pm 30$ & $61 \pm 4$ & $58 \pm 8$ & $56 \pm 6$ \\
\hline 20 & $295 \pm 28$ & $304 \pm 35$ & $300 \pm 30$ & $59 \pm 7$ & $65 \pm 12$ & $54 \pm 9$ \\
\hline 30 & $272 \pm 23$ & $269 \pm 28$ & $280 \pm 20$ & $50 \pm 9$ & $53 \pm 9$ & $51 \pm 12$ \\
\hline 50 & $245 \pm 32$ & $241 \pm 35$ & $250 \pm 35$ & $45 \pm 8$ & $45 \pm 13$ & $41 \pm 10$ \\
\hline
\end{tabular}

The data are mean \pm SEM of quadruplicate independent experiments. After the cells had been incubated with each concentration of $\mathrm{LiCl}, \mathrm{NaCl}$, or $\mathrm{NH}_{4} \mathrm{Cl}$ for 30 minutes, they were stimulated with $1 \mathrm{mM}$ carbamylcholine. Immediately before stimulation, $100 \mu \mathrm{M}$ L-NMMA, or vehicle were added. The levels of nitrite/nitrate in the incubation medium, that was collected 30 seconds after stimulation, were determined using the Griess reaction. 


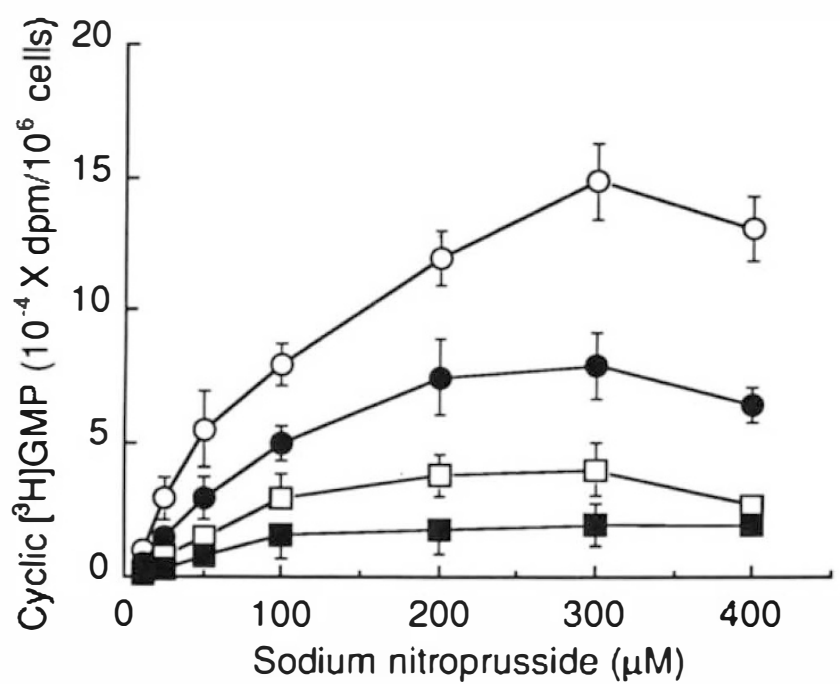

Figure 3. Effect of $10(\bigcirc), 25(\square)$, and $50(\square) \mathrm{mM} \mathrm{LiCl}$ on several concentrations of SNP-activated cyclic GMP formation in intact cells. Cells not exposed to $\mathrm{LiCl}(\mathrm{O})$ responded maximally to $300 \mu \mathrm{M}$ SNP. For circles and vertical bars, see legend in Figure 1.

significantly inhibited by preincubation with $100 \mu \mathrm{M}$ L-NMMA (Figure 1). In intact N1E-115 cells, $\mathrm{LiCl}$, as well as $\mathrm{NaCl}$ and $\mathrm{NH}_{4} \mathrm{Cl}$, exerted no significant inhibitory effects on carbamylcholine $(1 \mathrm{mM})$-stimulated elevation of nitrite/nitrate levels (Table 1).

\section{Effects of LiCl on SNP-induced Cyclic GMP Levels in Intact N1E-115 Cells}

In intact cells, elevation of the cyclic GMP levels elicited by $300 \mu \mathrm{M}$ SNP was inhibited by pretreatment with several concentrations of $\mathrm{LiCl}$ for 30 minutes in a dosedependent manner (Figure 2). $\mathrm{IC}_{50}$ was $10 \pm 2 \mathrm{mM}$ $(n=4) . \mathrm{NaCl}$ and $\mathrm{NH}_{4} \mathrm{Cl}$ had no significant inhibitory effects, but did appear to suppress the response at levels higher than $30 \mathrm{mM}$ because of high osmolarity (Figure 2). Elevation of the cyclic GMP levels elicited by 300 $\mu \mathrm{M}$ SNP was maximal in intact cells. Concentrations of SNP higher than $400 \mu \mathrm{M}$ decreased this response (Figure 3). $\mathrm{LiCl}$ inhibited cyclic GMP formation induced by various concentrations of SNP, and this inhibition by $\mathrm{LiCl}$ was not restored by SNP doses as high as 300 $\mu \mathrm{M}$ (Figure 3).

\section{Effects of LiCl on Cyclic GMP Levels in a Crude Homogenate of N1E-115 Cells}

In a crude homogenate of N1E- 115 cells, $\mathrm{LiCl}$ inhibited SNP (from $10^{-8}$ to $10^{-5} \mathrm{M}$ )-activated cyclic GMP formation in a dose-dependent manner (Figure 4). Up to $10^{-5} \mathrm{M}$ SNP did not restore the inhibition by 10,25 , or $50 \mathrm{mM} \mathrm{LiCl}$, though a concentration higher than $10^{-4} \mathrm{M}$ did appear to restore this inhibition.

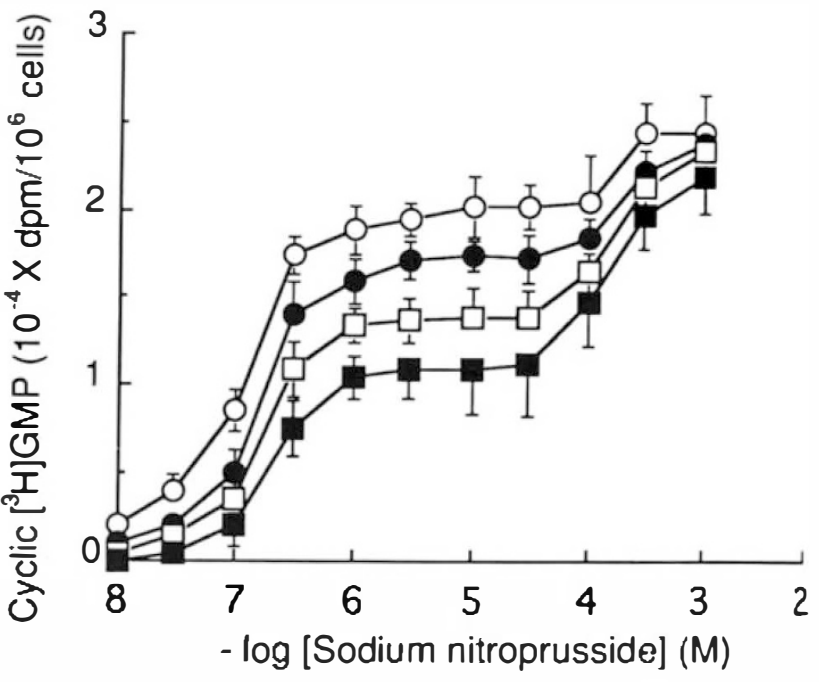

Figure 4. Effect of $0(\bigcirc), 10(\bigcirc), 25(\square)$, and $50(\square) \mathrm{mM} \mathrm{LiCl}$ on several concentrations of SNP-activated cyclic GMP formation in a cellular homogenate of N1E-115 cells. For circles and vertical bars, see legend in Figure 1.

\section{DISCUSSION}

We investigated the effects of $\mathrm{Li}^{+}$on muscarinic receptor-mediated $\mathrm{NO}$ generation and activation of GCase using a mouse neuroblastoma clone, N1E-115. We previously reported that $\mathrm{Li}^{+}$inhibits muscarinic receptor-activated cyclic GMP formation in N1E-115 cells (Kanba and Richelson 1984). There is agreement that activation of soluble GCase after receptor activation is a consequence of receptor mediated $\mathrm{Ca}^{2+}$ influx and activation of NOS (Dunnwiddie and Hoffer 1982; Knowles et al. 1989). Although the mechanism by which $\mathrm{Li}^{+}$inhibits cyclic GMP formation remains speculative, $\mathrm{Li}^{+}$is known to increase rather than decrease cellular $\mathrm{Ca}^{2+}$ levels by affecting transmembrane $\mathrm{Na}^{+} / \mathrm{Ca}^{2+}$ exchange processes (Aldenhoff and Lux 1984). Consequently, we hypothesized that $\mathrm{Li}^{+}$may exert its inhibitory actions by inhibiting the activation of either NOS or GCase.

Because carbamylcholine enhanced the levels of nitrite/nitrate in a dose-dependent manner and the increase in these levels was significantly inhibited by preincubation with $100 \mu \mathrm{M}$ L-NMMA (Figure 1), it was suggested that the elevated nitrite/nitrate levels reflect $\mathrm{NO}$ production/release from L-arginine following the activation of muscarinic receptors. Because incubation with $\mathrm{LiCl}$ for 30 minutes, which appeared to be enough time to inhibit receptor-mediated cyclic GMP formation (Kanba et al. 1986), did not reduce nitrite/nitrate levels in the incubation medium (Table 1), it was suggested that $\mathrm{Li}^{+}$does not affect receptor-mediated activation of NOS and that interference with the activation of NOS cannot explain the described inhibitory effects of $\mathrm{Li}^{+}$ on cyclic GMP formation. 
It is known that certain cofactors including tetrahydrobiopterine, calcium-calmodulin, flavin mononucleotide, flavin adenine dinucleotide, and heme are necessary for NO synthase to be activated (Nathan 1992). Considering the effects of $\mathrm{Li}^{+}$on $\mathrm{Ca}^{2+}$ influx (Aldenhoff and Lux 1984), it was expected that $\mathrm{Li}^{+}$ might change the activity of NOS by affecting activation of the calcium-calmodulin system. However, our results indicate that $\mathrm{Li}^{+}$does not affect the receptormediated activation of NOS. We cannot explain why $\mathrm{Li}^{+}$did not exert the expected action on NO synthesis, despite its effects on $\mathrm{Ca}^{2+}$ influx.

The $\mathrm{IC}_{50}$ of $\mathrm{LiCl}$ for cyclic GMP formation induced by NO donor SNP in intact cells was consistent with that for carbamylcholine-induced cyclic GMP formation in intact cells, which we previously reported (Figure 2) (Kanba and Richelson 1984). Because dose-dependent inhibition by $\mathrm{LiCl}$ was observed in both the intact cells and a crude cellular homogenate (Figure 3, Figure 4), we speculate that $\mathrm{Li}^{+}$is capable of inhibiting cyclic GMP formation without mediating receptor activation. $\mathrm{SNP}$ is known to activate GCase by producing NO enzymatically in the cells. Several oxidizing agents, such as methylene blue and $\mathrm{KFe}(\mathrm{CN})_{6}$, also inhibit SNP. induced cyclic GMP accumulation by converting NO to higher nitrogen oxides (Waldmann and Murad 1987). $\mathrm{Li}^{+}$does not share these oxidizing properties and may act via other mechanisms; therefore, thesefindings suggest that $\mathrm{LiCl}$ acts directly on GCase to inhibit the NOmediated activation.

Inhibition of cyclic GMP formation by $\mathrm{LiCl}$ was not restored by stimulation with $300 \mu \mathrm{M}$ SNP in intact cells. Because of SNP's inherent cytotoxicity in intact cells, we did not examine if this response was restored at concentrations of SNP higher than $400 \mu \mathrm{M}$. It did appear to be restored by higher concentrations of SNP in the experiments using cell homogenates. The reason for the biphasic inhibition curve is unknown. It is possible that $\mathrm{Li}^{+}$acts directly at the catalytic subunit of GCase by modifying substrate binding at lower levels and that $\mathrm{Li}^{+}$affects the activation subunit by interfering with reactions of $\mathrm{NO}$ at higher levels. In addition, because SNP is known to activate soluble GCase through multiple catalytic sites with different $\mathrm{Km}$ values (Lewicki et al. 1982), inhibition of GCase activity may occur at different catalytic sites depending upon the concentration of $\mathrm{Li}^{+}$.

The clinically effective concentration of $\mathrm{Li}^{+}$is much lower than the GCase inhibiting dose observed in thisstudy; however, a recent report showed that therapeutic concentrations of $\mathrm{Li}^{+}$inhibit SNP-induced accumulation of cyclic GMP in human lymphocytes (Schubert et al. 1991). Jope et al. (1992) reported that cyclic GMP production was reduced by acute and chronic administration of a therapeutic concentration of $\mathrm{Li}^{+}$. Furthermore, methylene blue which also in- hibits SNP-induced cyclic GMP formation has been proven to have a prophylactic effect in manic-depressive disorder like $\mathrm{Li}^{+}$(Naylor et al. 1986); thus, it is interesting to know if other cyclic GMP inhibiting agents would have a similar clinical effect.

In summary, it was suggested that $\mathrm{Li}^{+}$directly inhibits GCase activation without inhibition of receptormediated NO generation.

\section{ACKNOWLEDGMENTS}

This work was supported in part by Keio Gijuku Academic Development Funds, a Research Grant for Nervous and Mental Disorders from the Ministry of Health and Welfare and a Research Grant from Ohme Keiyu Hospital (Director: Nobuo Otsuka, M.D.).

\section{REFERENCES}

Aldenhoff JB, Lux HD (1984): Lithium und kalziumabhängige Zell-funktionen. Der Beitrag eines membranphysiologischen Untersuchungsansatzes zur Erklärung therapeutischer Lithiumwirkungen. Fortschr Neurol Psy chiatr 52:152-163

Arroyo CM, Forray C (1991): Activation of cyclic GMP formation in mouse neuroblastoma cells by a labile nitroxyl radical. An electron paramagnetic resonance/spin trapping study. Eur J Pharmacol 208:157-161

Berridge MJ (1984): Inositol triphosphate and diacylglycerol as second messengers. Biochem J 220:345-360

Cade JFM (1949): Lithium salts in the treatment of psychotic excitement. Med J Aust 36:349-352

Dunnwiddie TV, Hoffer BJ (1982): The role of cyclic nucleotides in the nervous system. In Kebabian JW, Nathanson JA (eds), Cyclic nucleotides 2. Springer, Berlin Heidelberg New York, pp 389-445

Garthwaite J (1991): Glutamate, nitric oxide and cell-cell signaling in the nervous system. Trends Neurosci 14:60-67

Hallcher LM, Scherman WR (1980): The effects of lithium ion and other agents on the activity of myo-inositol-1-phosphatase from bovine brain. J Biol Chem 255:10896-10901

Hishikawa K, Nakaki T, Tsuda M, Esumi H, Ohshima H, Suzuki H, Saruta T, Kato R (1992): Effect of systemic $\mathrm{L}$-arginine administration on hemodynamics and nitric oxide release in man. Jpn Heart J 33:41-48

Hokin MR, Hokin LE (1953): Enzyme secretion and the incorporation of P32 into phospholipids of pancreas slices. J Biol Chem 203:967-977

Jope RS, Song L, Kolasa K (1992): Inositol trisphosphate, cyclic AMP, and cyclic GMP in rat brain regions after lithium and seizures. Biol. Psychiatry 31:505-514

Kanba S, Pfenning M, Kanba KS, Richelson E (1986): Lithium ions have a potent and selective inhibitory effect on cyclic GMP formation stimulated by neurotensin, angiotensin II and bradykinin. Eur J Pharmacol 126:111-116

Kanba S, Richelson E (1984): Antimuscarinic effect of lithium. New Engl J Med 310:989-990 
Kanba S, Yagi G, Nakaki T, Kato R, Richelson E (1991): Potentiation by a sodium channel activator of effects of lithium ion on cyclic AMP, cyclic GMP and inositol phosphates. Neuropharmacology 30:497-500

Knowles RG, Palacios M, Palmer RMJ, Moncada S (1989): Formation of nitric oxide from L-arginine in the central nervous system: A transduction mechanism for stimulation of the soluble guanylate cyclase. Proc Natl Acad Sci USA $86: 5159-5162$

Lewicki JA, Brandwein HJ, Mittal CR, Arnold WP, Murad F (1982): Properties of purified soluble guanylate cyclase activated by nitric oxide and sodium nitroprusside. J Cycl Nucl Res 8:17-25

Naylor GJ, Martin SE, Hopwood SE, Watson Y (1986): A twoyear double-blind crossover trial of the prophylactic effect of methylene blue in manic-depressive psychosis. Biol. Psychiatry 21:915-920

Richelson E, Prendergast FG, Divinetz-Romero S (1978): Muscarinic receptor-mediated cyclic GMP formation by cultured nerve cells: Ionic dependence and effects on local anesthetics. Biochem Pharmacol 27:2039-2048

Schou M (1968): Lithium in psychiatric therapy and prophylaxis. J Psychiatr Res 6:67-95

Schubert T, Stoll L, Müller WE (1991): Therapeutic concentrations of lithium and carbamazepine inhibit cGMP accumulation in human lymphocytes. A clinical modelfor a possible common mechanism of action? Psychopharmacology 104:45-50

Waldmann SA, Murad F (1987): Cyclic GMP synthesis and function. Pharmacol Rev 39:163-196 